\title{
Fikcje cudzoziemczyzny, czyli paradoks „obcobrzmiącości” ${ }^{1}$
}

\footnotetext{
1 Jest to V rozdział książki Davida Bellosa Is That a Fish in Your Ear. Translation and the Meaning of Everything, New York 2011.
}

\section{David Bellos}

Przez większą część zeszłego stulecia zarówno [anglojęzyczni] recenzenci, jak i zwykli czytelnicy, chcąc podkreślić wybitność danego przekładu, stwierdzali zazwyczaj, że brzmi on tak, jakby oryginalnie został napisany po angielsku. Pusta to jednak pochwała, skoro ta sama wspólnota recenzentów i czytelników często nie potrafiła wykryć, że rzekomy przekład w istocie naprawdę został po prostu oryginalnie napisany po angielsku. Przypisywanie wysokiej rangi naturalności i potoczystości „języka docelowego” czy „przyjmującego” jest w świecie anglojęzycznym silnie związane ze współczesną kulturą przekładu. Chociaż słychać też głosy przeciwne. Kiedy powieść detektywistyczna osadzona w Paryżu pozwala swoim bohaterom myśleć i przemawiać potoczystą angielszczyzną, nawet jeśli tułają się po bulwarze Saint-Germain, piją likier Pernod, wcinają foie gras czy inne ragoût - to coś tu jest nie tak. Jaki pożytek z czytania do poduszki francuskiego kryminału, jeśli będzie pozbawiony aury francuskości? Czy nie wolelibyśmy raczej, żeby francuski detektyw brzmiał z francuska? Przekład udomawiający, który galijskich zbirów grabi z ich francuskości, bywał oskarżany przez krytyków o „etnocentryczną przemoc"1. Etyka przekładu, twierdzą owi krytycy, powinna powstrzymywać tłumaczy przed wymazywaniem z języka wyjściowego wszystkiego, co pobrzmiewa obcością.

Jak należałoby zatem tę obcość obcego reprezentować w przekładzie? Jean d’Alembert, matematyk i filozof, a także współredaktor Encyklopedii Diderota, już w 1763 roku wpadł na pomysł, jak na to pytanie odpowiedzieć:

Sposób mówienia obcokrajowców [po francusku] dostarcza modelu dla dobrego przekładu. Oryginał powinien bowiem mówić w naszym języku nie tyle z podejrzliwą ostrożnością, jaką darzymy język ojczysty, co z wytworną swobodą, która pozwala pożyczać cechy z jednego języka, by wzbogacić nimi inny. W ten sposób przekład może posiąść wszystkie te cechy, które czynią go godnym pochwały - naturalność i gładkość wymowy, naznaczone geniuszem oryginału, a zarazem ów dodatkowy posmak swojskości uzyskany poprzez ukazanie jej w obcym świetle².

\footnotetext{
${ }^{1}$ L. Venuti, The Translator's Invisibility: A History of Translation, New York 1995, s. 20 i nast.

2 J.R. d'Alembert, Observations sur l'art de traduire, w: Mélanges de littérature et de philosophie, vol. 3, Amsterdam 1763, s.18 [przekład ang. D. Bellos, tłum. z ang. I.O.].
} 
Ryzyko takiego podejścia tkwi w tym, że w wielu społecznych i historycznych kontekstach obcobrzmiącość przekładu - jak choćby lekko nienaturalna dykcja prawdziwego obcokrajowca mówiącego po francusku (po angielsku, po niemiecku...) - może zostać odrzucona jako zbyt niechlujna, nieautentyczna czy jeszcze coś gorszego.

W istocie najprostszym sposobem nadania tekstowi obcego brzmienia jest zostawienie niektórych jego części w oryginale. Taka konwencja obowiązywała w Wielkiej Brytanii w romantyzmie. Na przykład w najwcześniejszych przekładach powieści znanej dziś po angielsku jako Dangerous Liaisons [pol. Niebezpieczne związki] bohaterowie zwracają się do siebie za pomocą francuskiej tytulatury (monsieur le vicomte, madame la présidente) i w sam środek angielskich zdań wplatają codzienne wyrażenia po francusku, jak Allez!, parbleu! czy ma foi! ${ }^{3}$. Podobnie w niedawnych przekładach powieści francuskiej pisarki Fred Vargas główny bohater, Jean-Baptiste Adamsberg, zachowuje swoją rangę commissaire’a i sprawuje władzę nad bandą brigadiersów, ale zwraca się do nich w angielszczyźnie ${ }^{4}$. $\mathrm{Na}$ tej samej zasadzie, polegającej na stosowaniu wybranych wtrętów obcojęzycznych, niemieccy oficerowie w większości hollywoodzkich filmów o II wojnie światowej rozmawiają po angielsku, regularnie przeplatając swoje wypowiedzi wtrąceniami typu jawohl, Gott im Himmel czy heil Hitler.

Ta metoda może mieć szersze zastosowanie zarówno w dziełach popularnych, jak i klasyce. Dubbingowana włoska wersja Deszczowej piosenki, mimo że czyni cuda, jeśli chodzi o synchronizację ruchu ust w przekładzie dowcipnych dialogów, to ścieżkę dźwiękową tytułowego utworu pozostawia w wersji niezmienionej, angielskiej. Natomiast we współczesnej słynnej chińskiej adaptacji Króla Leara Kordelia przemawia słowami Szekspira - mówi ojcu w oczy prawdę w oryginalnym języku sztuki ${ }^{5}$.

Przeważnie jednak przekłady tylko symulują obcobrzmiącość dzieł obcych. W istocie zaś można sprostać wyzwaniu, jakim jest napisanie czegoś, co dla użytkowników innego języka będzie brzmiało jak angielski, w ogóle nie używając angielszczyzny.

Angielszczyznę - w popularnych piosenkach, w telewizji itp. - słyszą na całym świecie miliony odbiorców, którzy nie rozumieją ani słowa z tych tekstów, sloganów i newsów. W rezultacie mamy ogromną liczbę ludzi, którzy rozpoznają fonologię angielskiego - brzmienie angielszczyzny - w ogóle nie znając jego gramatyki ani słownictwa. Jakieś czterdzieści lat temu znany włoski piosenkarz Adriano Celentano zaprezentował musicalowy numer, w którym udawał nauczyciela pokazującego klasie, że nie trzeba rozumieć ani słowa po angielsku, żeby wiedzieć, jak brzmi ten język. Zaśpiewana do chwytliwej melodii, „Prisencolinensinainciusol ol rait" to dowcipna i zaskakująca symulacja brzmienia angielszczyzny stworzona w ogóle bez użycia tego języka. Jednak transkrypcja tego „anglobełkotu” na zapis tekstowy dowodzi, że

\footnotetext{
${ }^{3} \mathrm{M} . \mathrm{C}^{* * * *}$ de $\mathrm{L}^{* * *}$, Dangerous connections: or, letters collected in a society, and published for the instruction of other societies, London 1784.

${ }^{4}$ F. Vargas, Have Mercy on Us All, przeł. D. Bellos, London 2003. Imię pisarki jest skrótem od Frederique. W Polsce powieści Vargas wydają Prószyński i S-ka oraz Wydawnictwo Sonia Draga - przyp. tłum.

${ }^{5}$ W reżyserii Davida Ka-Shing dla Yellow Earth Theatre and Shanghai Dramatic Arts Center, spektakl wystawiony w Stratford nad Avon, w Londynie i w Szanghaju w roku 2006. W tej adaptacji szekspirowskiego dramatu Lear jest Chińczykiem, właścicielem globalnego imperium biznesowego. Kordelia, jego córka, w odróżnieniu od swoich sióstr, które w eleganckiej chińszczyźnie przypochlebiają się ojcu, nie włada chińskim, gdyż została wyedukowana w Anglii. Na pytania ojca odpowiada lakonicznym „nothing”, co daje początek tragicznym wydarzeniom [przyp. tłum.].
} 
może on brzmieć „po angielsku” tylko wówczas, kiedy zostanie wypowiedziany (na głos albo w myślach) z zachowaniem standardowych reguł wymawiania tekstu pisanego w języku włoskim. Piosenka „Prisencolinensinainciusol ol rait”, którą można znaleźć na wielu aktualnie dostępnych stronach internetowych, niekiedy nawet łącznie z którąś z jej transkrypcji, to specyficznie włoska fikcja cudzoziemczyzny.

Równie udatnie można stworzyć sekwencję bezsensownych dźwięków, które będą brzmiały cudzoziemsko dla uszu angielskich. Słynnym przykładem jest utwór śpiewany przez Chaplina w Dzisiejszych czasach (1936). Grany przez niego bohater zatrudnia się jako śpiewający kelner i ląduje na restauracyjnym parkiecie obok zespołu, który piłuje właśnie francuski musicalowy numer Je cherche après Titine - ale nasz nieszczęśnik nie zna słów. Chaplin tańczy, wykonuje pantomimę i wygląda na coraz bardziej skonsternowanego. Paulette Goddard, która stoi za kulisami, bezgłośnie woła do niego „sing!”. Słowo to daje się odczytać z jej ust, ale dialog wypisano dodatkowo na ekranie: „Sing! Never mind the text”.

Wtedy Chaplin zaczyna w jakimś uogólnionym narzeczu romańskim śpiewać rymowankę, którą - wyłącznie na użytek osób anglojęzycznych - można przedstawić następująco:

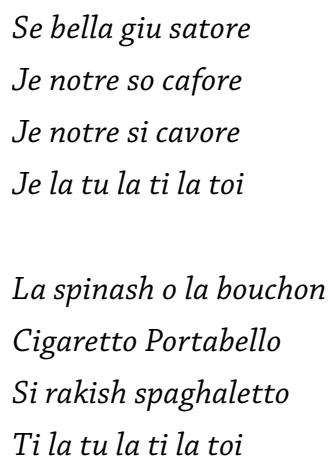

${ }^{6}$ Czyli „Śpiewaj! Tekst nieważny!” [przyp. tłum.]. 


\section{Se motra so la sonta \\ Chi vossa l'otra volta \\ Li zoscha si catonta \\ Tra la la la la la la}

Dla użytkownika angielszczyzny brzmi to jak francuski - albo włoski czy hiszpański - jeśli nie zna tych języków inaczej niż tylko ze słuchu. Wersy te nie mają żadnego znaczenia, a tylko parę słów jest faktycznie francuskich, włoskich czy hiszpańskich. Wniosek jest taki: nie musisz mówić sensownie, żeby brzmieć z cudzoziemska. Dla starożytnych Greków obca mowa brzmiała jak nieartykułowany bełkot va-va-va, dlatego wszystkich niemówiących po grecku nazywali varvaros, barbarzyńcami. Brzmieć obco znaczy mówić bełkotliwie, niewyraźnie, być durnym, niedorozwiniętym: polskie i rosyjskie słowa „Niemiec” i „немец” pochodzą od „niemy”, „niemowa”, a w najstarszych wariantach tych języków odnosiły się do wszelkich cudzoziemców nieznających lokalnej mowy.

Wszelako po roku 1980 wiele utworów ze współczesnego kanonu europejskiego ponownie przełożono na angielski i francuski. Ich tłumacze otwarcie dążyli do tego, by znane i już oswojone arcydzieła w rodzaju Zbrodni i kary czy Przemiany zabrzmiały bardziej obco - co wcale nie oznacza, że miały zabrzmieć bezsensownie.

Dziewiętnastowieczni tłumacze często zostawiali znane słowa i wyrażenia w oryginale (głównie wtedy, gdy oryginał był po francusku), lecz jest to chwyt rzadko stosowany we współczesnych przekładach, nawet tych, które dążą do „egzotyzacji”. Kiedy Gregor Samsa budzi się pewnego ranka i stwierdza, że nocą zmienił się w owada, nie wykrzykuje przecież w najnowszym angielskim przekładzie „Ach, Gott!” ani Iwan Fiodorowicz nie mówi „Это вот как” w żadnym z dostępnych przekładów Braci Karamazow. Gdyby te powieści zostały napisane po francusku i przełożone na angielski zgodnie z konwencją tłumaczenia $\mathrm{z}$ lat dwudziestych XIX wieku, moglibyśmy mieć pewność, że Samsa zawołałby „Oh mon Dieu!” a Iwan Fiodorowicz rzekłby „Alors, voilà”.

Pewne kwestie uległy zmianie, i to nie we francuskim, niemieckim czy rosyjskim, a w samej angielszczyźnie. We współczesnej kulturze języka od anglojęzycznych czytelników nie oczekuje się, że będą w stanie rozpoznać niemieckie czy rosyjskie odpowiedniki konwersacyjnych wtrętów w rodzaju „Good God” czy „well, now”, ale brytyjska kultura języka epoki wiktoriańskiej i edwardiańskiej zakładała, że czytelnicy są zaznajomieni z francuskimi zawołaniami tego rodzaju.

Zachowanie elementów tekstu źródłowego w przekładzie może służyć celom dydaktycznym i społecznym. Pozwala czytelnikom przyswoić sobie to, czego nie nauczyli się w szkole, lub odświeżyć na wpół zapomniane lekcje w ich pamięci. Zachowanie oryginalnych wyrażeń w jasno określonych i łatwych do rozszyfrowania sytuacjach komunikacyjnych, takich jak powitania czy okrzyki, daje czytelnikom coś, czego mogliby w zasadzie oczekiwać od przekładu: mgliste wrażenie, że czytają powieść po francusku. Gdy czytanie po francusku było istotnym wyznacznikiem kulturowych dystynkcji, takie odczucie mogło być wielce satysfakcjonujące.

Sporadyczne albo „ozdobne” obce wtręty dają się łatwo zastosować jedynie w przekładzie pomiędzy językami o utartej relacji. Przez wiele wieków język francuski był wymogiem wyższej edukacji w świecie anglosaskim i stąd okruchy francuszczyzny stały się częścią ogólnego zasobu 
lingwistycznego wykształconego Anglika. Takie elementy zaczerpnięte z innego języka znaczyły tyle co „oto mowa francuska”, z czego płynął miły wniosek, że „umiem trochę mówić po francusku". Efektu, jaki ta konkluzja wywierała na poczucie własnej wartości u czytelnika, nie psuł nawet fakt, że oryginalne znaczenie takich fraz jak parbleu czy ma foi w istocie się zatarło. W czasach gdy władanie francuskim było wyznacznikiem przynależności do klasy ludzi wykształconych, czytanie francuskich powieści w przekładzie miało po części za zadanie przybliżyć mniej wyedukowanym czytelnikom dobra kultury, które owe elity już posiadały. Im więcej francuskiego zostawiono w przekładzie $\mathrm{z}$ francuskiego, tym lepiej takie tłumaczenie spełniało potrzeby czytelnika.

Nie da się już tego samego zrobić z językiem rosyjskim czy niemieckim - uczy się ich dziś jedynie garstka studentów. Znajomość jednego z tych języków, czy wręcz obydwu, nie ma żadnego znaczenia dla hierarchii kulturowej w świecie anglosaskim - znaczy tylko tyle, że prawdopodobnie jesteś lingwistą, astronautą albo inżynierem z branży motoryzacyjnej.

Jak można zatem reprezentować „rosyjskość” czy „niemieckość” w dziele napisanym po angielsku? Konwencjonalne rozwiązania tej zagwozdki nie są niczym więcej niż właśnie kulturowymi konwencjami, powstałymi w anglojęzycznej domenie na kanwie kontaktów historycznych, wzorców imigracji oraz tekstów popkultury (w rodzaju filmowej satyry na zimną wojnę Doktor Strangelove, czyli jak przestałem się martwić i pokochałem bombę). Ale gdybyśmy mieli zastosować się do zaleceń d'Alemberta, to próbowalibyśmy sprawić, że Kafka czy Dostojewski zabrzmią jak cudzoziemcy (którymi przecież dla nas byli...), każąc im posługiwać się angielszczyzną „upstrzoną” cechami typowymi dla osób niebędących rodzimymi użytkownikami tego języka.

Oczywiście Kafka i Dostojewski, niezależnie od ich autorskich stylów, po niemiecku i po rosyjsku nie będą brzmieli cudzoziemsko w odczuciu czytelników, dla których są to języki ojczyste. Cudzoziemskość w przekładzie jest siłą rzeczy naddana w stosunku do oryginału. Zarówno w paplaninie Chaplina, jak i w retranslacjach klasyków literatury, musi być konstruowana w obrębie języka docelowego. Dlatego „obcobrzmiącość” przekładu próbującego dostarczyć czytelnikowi przebłysków tego, czym faktycznie jest tekst źródłowy, może jedynie reprodukować i pogłębiać wyobrażenie cudzoziemczyzny, które już istnieje w kulturze docelowej.

Friedrich Schleiermacher, wybitny filozof dziewiętnastowieczny oraz tłumacz dzieł Platona na niemiecki, roztrząsał ów fundamentalny paradoks w swoim wielokrotnie cytowanym tekście „O różnych metodach tłumaczenia”. Jego stwierdzenie, iż „można nawet powiedzieć, że cel: tłumaczyć tak, jak autor napisałby oryginalnie w języku przekładu, jest nie tylko nieosiągalny, ale także sam w sobie błahy i nieistotny"7, zwykle interpretuje się jako dystansowanie się przezeń od tłumaczenia potoczystego, niewidzialnego, „normalizującego”. Ale tę słynną wypowiedź można też interpretować odwrotnie: że mianowicie tak samo sztuczny byłby Kafka jako niby-Niemiec, który pisze po angielsku, jak sztuczna byłaby przemiana Gregora Samsy w potwornego robaka dokonująca się w sypialni mieszkania w Hoboken, stan New Jersey.

Dlaczego w ogóle mielibyśmy sobie życzyć, żeby Kafka pobrzmiewał z niemiecka? W niemczyźnie Kafka nie brzmi „z niemiecka” - brzmi po prostu jak Kafka. Ale dla ucha anglojęzycznej

\footnotetext{
${ }^{7}$ F. Schleiermacher, O różnych metodach tłumaczenia, przeł. P. Bukowski, „Przekładaniec” 2010, nr 21, s. 27.
} 
osoby, która uczyła się niemieckiego, lecz nie włada tym językiem w pełni naturalnie, cała proza Kafki do pewnego stopnia „brzmi z niemiecka” właśnie dlatego, że język niemiecki nie jest językiem ojczystym takiego odbiorcy. Jeśli tłumacz lub tłumaczka pragnie przekazać odbiorcy przekładu swoje własne doświadczenie lektury oryginału, bodaj najlepsze, co może zrobić, to uczynić Kafkę pobrzmiewającym z niemiecka w angielszczyźnie.

Schleiermacher w istocie uważa, że z wyjątkiem „owych znakomitych mężów władających równie biegle kilkoma językami”, wszyscy „odczuwać będą obcość”, czytając dzieła napisane w innym niż ich ojczysty języku. Zadaniem tłumacza jest więc „zaszczepić w czytelnikach swego przekładu to właśnie uczucie, że mają przed sobą twór obcy”. A jest to szczególnie trudne i raczej paradoksalne zadanie, jeśli nie możesz odwołać się do konwencji, które już są obecne w kulturze docelowej i które reprezentują „obcego” charakterystycznego dla kultury języka tekstu źródłowego.

Obcobrzmiącość jest zatem realną opcją dla tłumacza, jeśli pracuje on nad przekładem z języka, który ma już ugruntowaną relację z językiem docelowym. Najdłuższą i najintensywniejszą relację tego typu można w anglosaskim świecie zaobserwować $\mathrm{z}$ związku z językiem francuskim. W Stanach Zjednoczonych język hiszpański w ostatnich latach stał się najbardziej rozpoznawalnym obcym językiem dla większości młodych czytelników. Dlatego angielszczyzna potrafi na wiele sposobów oddawać francuskość, a amerykański angielski ma też cały wachlarz chwytów służących do przedstawiania hiszpańskiego. Możemy też, choć w mniejszym stopniu, przedstawiać niemieckość, a w jeszcze bardziej ograniczonym - akcenty włoskie. Ale co z językiem joruba? Albo marathi? Albo czuwaskim? Lub innym z niemal siedmiu tysięcy pozostałych języków? Żaden z dostępnych anglojęzycznemu pisarzowi chwytów językowych nie sprawi, że tekst będzie „brzmieć jak joruba" czy wywoływać wrażenie tego, jak to jest pisać po czuwasku. Nie mamy o tym bladego pojęcia. Projekt tworzenia przekładów, które w swoim brzmieniu zachowają ślad obcości dzieła tłumaczonego, daje się wdrażać tylko tam, gdzie oryginał wcale nie jest aż taki obcy.

Jednocześnie teksty tłumaczone mogą zainteresowanych czytelników nauczyć czegoś o brzmieniu i ogólnym wrażeniu, a nawet właściwościach składni języka oryginału. Oryginały zresztą też - Things Fall Apart ${ }^{8}$ Chinuy Achebego wprowadza elementy języków afrykańskich, a Upamanyu Chatterjee w książce English, August daje niezły wgląd w słownictwo języka hindi czy bengalskiego. Ale kiedy obcość nie jest tematyzowana - nie jest pierwszoplanowym przedmiotem opowieści - wymagana jest pewna wiedza na temat języka oryginału, żeby w ogóle móc wywołać efekt obcości. Żeby w ogóle zauważyć, że zdanie z niemieckiego jest przekładem wyobcowującym, trzeba wiedzieć, że w niemieckim w zdaniach podrzędnych czasownik daje się na końcu zdania. Inaczej wyjdzie komicznie, niechlujnie, bezsensownie itd. - lecz wcale nie „z niemiecka”.

W Dzisiejszych czasach i w piosence Adriano Celentano mamy do czynienia z zabawą polegającą na imitowaniu obcobrzmiącości w śpiewie i w mowie. Najnowszy angielski przekład Przemiany też mógłby wybrzmieć w głowie czytelnika jako niemieckopodobny. Pierwsze słowa Gregora Samsy wypowiedziane w mowie niezależnej

- "Oh God," he thought, "what a gruelling job I've picked! Day in, day out - on the road."

${ }^{8}$ Powieść przełożona na polski dwukrotnie, po raz pierwszy przez Małgorzatę Żbikowską jako Świat się rozpada (1989), powtórnie przez Jolantę Kozak jako Wszystko rozpada się (2009) - przyp. tłum. 
- zostałyby wówczas odebrane jako pisemna reprezentacja dźwięków, których transkrypcja fonetyczna wyglądałaby mniej więcej tak:

"Och Gott," e saut, "vot a kruling tschop aif picked! Tay in, tau out - on ze rote."

To oczywiście zupełna głupota - żaden tłumacz nie chciałby, żeby jego przekład wybrzmiewał z obcym akcentem. Niemniej jednak musimy odpowiedzieć sobie na pytanie: jeśli nie o to chodzi w obcobrzmiącości przekładu tekstu w obcym języku, to czym właściwie ma owa obcobrzmiącość być? Co pozwala nam ocenić, czy poniższy passus zawiera w sobie ślady francuskości Jacques'a Derridy, czy po prostu jest piekielnie zawiły?

Pozytywne i klasyczne nauki o piśmie mogą już tylko tłumić ten typ pytania. Do pewnego stopnia represja ta jest nawet konieczna ze względu na postęp badań pozytywnych [positive researches]. Pominąwszy to, że onto-fenomenologiczne pytanie o istotę, czyli źródło pisma, postawione byłoby jeszcze w ramach filozofującej logiki, mogłoby ono jedynie obezwładniać czy też wyjaławiać historyczne i typologiczne badanie faktów.

Toteż intencja nasza nie polega na tym, by to przedwstępne pytanie, to proste, konieczne i w pewien sposób łatwe pytanie de iure położyć na szalę wraz z mocą i skutecznością badań pozytywnych, jakich jesteśmy dzisiaj świadkami. Geneza i system pisma nigdy nie dały sposobności głębokim, rozległym i śmiałym eksploracjom. W tym mniejszym stopniu chodzi o położenie na szalę pytania i ciężaru odkryć, że pytania są błahe. Jeśli zaś to pytanie nie jest całkiem błahe, to być może dlatego, że konsekwencje jego stłumienia sięgają samej treści badań, które w tym przypadku i mocą przywileju koncentrują się zawsze wokół problemów definicji i punktu wyjścia ${ }^{10}$.

Wiemy, że treść tego hermetycznego wyimka nie jest związana z tym, czy „brzmi jak” angielski czy nie - piosenka Celentano pokazała nam już, że można stworzyć kompletnie bezsensowne konkatenacje, które będą brzmiały idealnie po angielsku, jeśli fonetyczna angielskobrzmiącość jest tym, co chcemy osiągnąć. Jednak detalem, który naznacza ów tekst jako przekład z francuskiego, jest słowo research nienormatywnie użyte w liczbie mnogiej, researches ${ }^{11}$, podobnej z wyglądu do najzupełniej normalnego francuskiego słowa recherches. Może to zauważyć jedynie czytelnik znający język francuski tak samo dobrze jak język angielski - obcość researches nie będzie oczywista dla czytelnika wyłącznie anglojęzycznego, który mógłby równie dobrze skonstruować inną hipotezę na temat pochodzenia tego wyjątku lub wręcz zaakceptować go jako specyficzne czy techniczne pojęcie charakterystyczne dla tego konkretnego autora. Ale jeśli dwujęzyczny czytelnik ma jeszcze dodatkowo wiedzę na temat francuskojęzycznej nomenklatury filozoficznej, wówczas obecność słowa positive poprzedzającego słowo researches stanie się zrozumiała. Dwujęzyczny czytelnik może łatwo domyślić się, że positive researches oddaje oryginalne recherches positives. Osobnym problemem jest sens tej francuskiej frazy - tak mianowicie standardowo tłumaczy się na francuski angielskie empirical investigations, czyli „badania empiryczne”.

\footnotetext{
${ }^{9}$ Chodzi o zdanie, które w polskim przekładzie Juliusza Kydryńskiego brzmi następująco: „Ach, Boże - pomyślał - cóż za wyczerpujący zawód sobie obrałem! Dzień po dniu w podróży”. Gdyby miało zostać wypowiedziane z wyraźnym akcentem niemieckim, jego transkrypcja mogłaby wyglądać tak: „Ach, Posze - pomyshlau - tsush za fytsherpujoncy safut sopie oprauem! Tsień po tniu fpodrushy" - przyp. tłum.

${ }^{10}$ J. Derrida, O gramatologii, przeł. B. Banasiuk, Łódź 2011, s. 56.

${ }^{11}$ W przekładzie polskim jest to słowo „badań” i podnoszona przez Davida Bellosa kwestia związana z wyrażeniem positive researches tu się nie pojawia - przyp. tłum.
} 
Można by stwierdzić, że positive researches jest kiepskim tłumaczeniem utartego francuskiego wyrażenia, którego tłumacz najwyraźniej nie rozpoznał. Ale można by też dostrzec tu ślad brzmienia oryginału. I rzeczywiście, gdyby angielska fraza nie była wyczuwalną anomalią, nie bylibyśmy w stanie, że nie jest ona do końca angielska. Ale równie oczywiste jest to, że nie bylibyśmy w stanie zauważyć też „imitowanej francuskości” tej frazy, gdyby język francuski był nam zupełnie obcy.

Wsteczny przekład obcego pojęcia positive researches na wiele innych języków, w tym również współczesnej greki, dałby ten sam efekt - to znaczy pozwoliłby rozszyfrować jego znaczenie jako „badania empiryczne”. Ale bez informacji o tym, że dane dzieło było tłumaczone z języka A, sam przekład wyobcowujący nie pozwala zidentyfikować, jaki język był językiem źródłowym.

Przekład wyobcowujący nagina angielszczyznę do kształtów, które odzwierciedlają pewien ograniczony aspekt języka wyjściowego, jak szyk czy struktura zdania. Ale efekt wyobcowania opiera się tu przede wszystkim na przynajmniej pobieżnej znajomości kształtu i brzmienia obcego języka - a w cytowanym przykładzie tekstu Derridy przełożonego na angielski przez Gayatri Chakravorty Spivak na znajomości konkretnych elementów słownictwa obcego języka.

Wyobraźmy sobie powieść przełożoną z języka takiego jak hindi, w którym istnieją trzy sposoby adresowania rozmówcy: tu, tum oraz ap, odnoszące się do stopnia zażyłości - intymnej, przyjacielskiej i formalnej. Sposoby posługiwania się nimi stanowią istotny element znaczeniowy wypowiedzi bohaterów tej powieści i charakteryzują relacje między nimi. Czy tłumacz mógłby stworzyć lingwistyczną anomalię w angielszczyźnie, która by korespondowała z tym trójpodziałem „ty”? Oczywiście. Ale czy wówczas wiedzielibyśmy, że to cecha charakterystyczna języka hindi? Bez przypisu od tłumacza raczej nie - ponieważ nic nie wiemy o języku hindi.

Większość przekładów dokonuje się pomiędzy językami społeczności mających ze sobą styczność na płaszczyźnie kulturowej, ekonomicznej czy politycznej i dlatego często wykorzystuje się w nich formalne czy leksykalne zapożyczenia w celu zaakcentowania obcości - a także prestiżu - tekstów importowanych z zagranicy. W XVI wieku na przykład większość dzieł literackich i filozoficznych przeniesiono do języka francuskiego z języka włoskiego, tak jak wielu włoskich rzemieślników importowano do upiększania pałaców i zamków w całym kraju. Tłumacze tej epoki pisali po francusku, używając mnóstwa włoskich słów i zwrotów, ponieważ mieli poczucie, że ich czytelnicy albo już znali, albo powinni byli znać słowa i wyrażenia zapożyczone. Co więcej - uważali, że francuszczyzna będzie lepsza, jeśli się ją troszeczkę upodobni do języka włoskiego. W istocie proces „italianizowania” języka francuskiego trwa do dziś. Caban (kurtka dwurzędowa) oraz caleçon (męskie majtki) w waszej szafie, a jeśli macie fart, to także melon kantalupa (cantaloup) oraz kawior (caviar) w waszej lodówce, podobnie jak całą masę rzeczy zwykłych i uczonych, delikatnych i wybornych, nazwano po francusku za pomocą określeń wziętych z języka włoskiego, w większości przypadków za to przejęcie odpowiedzialni byli zaś tłumacze ${ }^{12}$.

Podobny typ leksykalnego wzbogacenia miał miejsce w XIX wieku, gdy niemieckojęzyczna ludność dążyła do podkreślenia odrębności i rosnącego jednoczenia się narodu. Niemieccy tłumacze świadomie importowali wiele słów z greki, francuskiego czy angielskiego nie tylko po to,

\footnotetext{
${ }^{12} \mathrm{M}$. Margarito, Une valise pour bien voyager... avec les ital-ianismes du français, „Synergies” 2008, nr 4, s. 63-73.
} 
żeby przybliżyć niemieckojęzycznym czytelnikom klasykę europejskiej literatury, lecz również z myślą o wzbogacaniu leksyki niemieckiej. Rozumowali następująco: francuski i angielski są językami europejskimi i mają wsparcie w potężnych państwach. Dlatego obcokrajowcy uczyli się mówić po francusku (albo, wprawdzie rzadziej, po angielsku). A jak język niemiecki miałby stać się nośnikiem silnej państwowości, jeśli inni nie chcieliby się go uczyć? I dlaczego mieliby się uczyć czytać po niemiecku, jeśli ów język nie byłby w stanie z łatwością przekazywać znaczeń zrodzonych w transnarodowych kulturach reprezentujących bogactwo cywilizacji europejskiej?

W świecie współczesnym tłumacze na języki „mniejsze” często postrzegają swoje zadanie jako obronę lub doskonalenie własnych języków - albo jako jedno i drugie naraz. Oto list, otrzymany niedawno od tłumacza z Tartu:

Mój ojczysty język, estoński, ma około miliona użytkowników. Niemniej jednak sądzę, że Życie. Instrukcja obsługi i mój język zasługują na siebie nawzajem. Tłumacząc Pereca, chcę dowieść, że język estoński jest wystarczająco bogaty i żywy, żeby sprostać trudnościom, jakie tego typu dzieło ze sobą niesie.

Przekład, rzecz jasna, może służyć celom narodowym, ale może też pełnić funkcję odwrotną i sprzyjać internacjonalizmowi. Współczesny pisarz francuskojęzyczny o pseudonimie Antoine Volodine w trafny sposób wyraził, dlaczego pragnie używać języka rodzimego tak, jakby to był język obcy. Dla niego francuski to nie tylko język Racine’a czy Voltaire’a. Jako że tłumaczeń na francuski dokonywano od wielu wieków, stał się on także językiem Puszkina, Szałamowa, Li Bai czy Márqueza. Nie będąc wcale uprzywilejowanym nośnikiem narodowej tożsamości, historii i kultury, ,jest pasem transmisyjnym dla kultur, filozofii i niepokojów niemających nic wspólnego z obyczajami francuskiej socjety czy frankofońskiego świata"13. Nie chodzi o to, że francuski z natury lub przeznaczenia jest językiem międzynarodowym, ale na odwrót - jedynie praktyka tłumaczeń na francuski uczyniła z niego narzędzie internacjonalizmu we współczesnym świecie. Dzięki długiej historii przekładów z obcych języków, francuski może być dziś nośnikiem wyrafinowanej, niepokojącej literatury, która według Volodine’a z natury miałaby być mu zupełnie obca.

Dlatego też niesłusznie byłoby uważać coraz częstsze przenikanie się angielskiego, francuskiego, niemieckiego i włoskiego, terminów i fraz z łaciny i greki, czy - jak w pisarstwie Volodine’a - języka rosyjskiego i chińskiego wyłącznie za produkt tego, co dzisiaj określa się mianem globalizacji. Globalizacja nie polega tylko na upowszechnianiu angielszczyzny w innych językach i kulturach - równie dobrze można ją zilustrować szerzeniem się języka pizzy i słownictwa związanego z kulturą makaronu w sklepikach i fast foodach na całym świecie. Jest ona również efektem długotrwałych starań tłumaczy, by ich własnym językom narodowym nadać status internacjonalny. W tym celu nie muszą wcale dokładać starań, by ich przekłady sugerowały obcość. Co więcej, jeśli faktycznie takie starania miały miejsce, to ich powodzenie wniwecz obróciło pierwotny cel, bo importowane lub imitowane słowa stały się teraz częścią języka przyjmującego do tego stopnia, że przestały być w nim obce.

Nie mniej niż czterdzieści procent haseł w każdym większym słowniku języka angielskiego to towar importowany. Zapożyczenie obce - słowo, zwrot czy struktura gramatyczna wniesiona przez któregoś tłumacza do naszego wspaniałego, tak irytująco plastycznego języka, by imito-

${ }^{13}$ A. Volodine, Écrire en français une littérature étrangère, „Chaoïd” 2002, nr 6. 
wać brzmienie oryginału - ma już wcześniej wytyczoną ścieżkę. I albo będzie odrzucone jako niechlujny, dziwaczny, wybrakowany akt translacji, albo zostanie wchłonięte, zagospodarowane, przyłączone i nie będzie już w ogóle obce.

Współczesnych prób dokonywania takich przekładów na język angielski, które sugerują obcość, nie można porównywać ze staraniami dawnych tłumaczy, by niemczyznę uczynić bliższą językowi angielskiemu, francuski bliższy włoskiemu, syryjski grece itd. Dzisiejsi zwolennicy przekładów wyobcowujących nie walczą o to, by angielski stał się językiem międzynarodowym, bo angielski już jest językiem międzynarodowym. Do pewnego stopnia próbują go wzbogacić, sięgając do zasobów językowych, którymi dysponują języki od angielszczyzny mocno oddalone. „Kiedy zostałem tłumaczem, podświadomie zacząłem działać na rzecz ożywienia i wzmocnienia samej angielszczyzny” - wyznał Richard Pevear w wywiadzie dla „New Yorkera” ${ }^{14}$. Jego twórczy projekt pisarski opiera się na pragnieniu, by współdzielić z czytelnikami konkretne odczucia, które towarzyszyły mu podczas lektury rosyjskich powieści. Autor często podkreśla, że nie włada biegle językiem rosyjskim, więc polega na swojej partnerce, która mu dostarcza surowe przekłady, później przez niego przetwarzane na wersję literacką ${ }^{15}$. Podobne strategie mogą stosować inni orędownicy dziwnych i obcobrzmiących stylów przekładu. Projekt stworzenia przekładu, który zadawałby możliwie najmniej „etnocentrycznego gwałtu” oryginałowi, niesie ze sobą ryzyko przeistoczenia się w coś zupełnie innego - w imitację dziwnego sposobu mówienia obcokrajowców.

Naturalnym sposobem przedstawienia obcości obcych wypowiedzi jest więc zostawienie ich w oryginale, w całości lub częściowo. Ten zabieg jest dostępny we wszystkich językach i - rzadziej lub częściej - używa się go w każdym z nich ${ }^{16}$.

Nie jest łatwo całkiem na serio reprezentować obcość języka obcego. A trzeba humoru Chaplina czy Celentano, żeby zrobić to na sposób komiczny, nikogo przy tym nie obrażając.

Głównym zadaniem przekładu jest oddanie znaczenia obcego tekstu. I samo to już jest, o czym się przekonamy, zadaniem wystarczająco skomplikowanym.

\section{Przełożyła Inez Okulska, redakcja przekładu: Ewa Kraskowska}

\footnotetext{
${ }^{14}$ D. Remnick, The Translation Wars, „The New Yorker”, November 7, 2005. Richard Pevear przekładał m.in. Dostojewskiego i Tołstoja, współpracując z żoną, Larissą Volokonski - przyp. tłum.

${ }^{15}$ Tamże. Zob. też krytyczną ocenę przekładów R. Peveara i L. Volokonsky przez Gary'ego Saula Morsona, The Pevearsion of Russian Literature, „Commentary” July-August 2010, <https://www.commentarymagazine.com/ articles/the-pevearsion-of-russian-literature/ $\geq$ [dostęp: 22.09.2018].

${ }^{16}$ W książce Mariusza Wilka The Journals of a White Sea Wolf, London 2003, tłumacz Danius Stok wykorzystuje tę metodę ze świetnym efektem.
} 


\title{
SŁOWA KLUCZOWE:
}

p r z e kła d

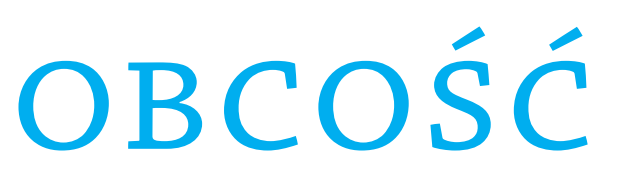

\begin{abstract}
Abstrakt:
Publikowany w tym numerze „Forum Poetyki” esej Davida Bellosa jest rozdziałem $\mathrm{z}$ jego książki pt. Is That a Fish in Your Ear (2011) i dotyczy zagadnień egzotyzacji w przekładzie oraz obcości przekładu. Autor zadaje tu m.in. pytanie o zasadność i sposoby zachowania śladów obcości tekstu źródłowego w tekście docelowym. Porusza także kwestię imitowania obcej mowy za pomocą różnych środków stylistycznych, ilustrując ją przykładami z dziedziny literatury, filmu i piosenki.
\end{abstract}




\section{NOTA O AUTORzE:}

David Bellos - profesor literatury francuskiej i literatury porównawczej, dyrektor studiów w zakresie przekładu i komunikacji interkulturowej na Uniwersytecie Princeton. Wybitny tłumacz literatury francuskiej na język angielski; autor biografii Georgesa Pereca (za którą otrzymał w 1994 Nagrodę Goncourtów), Jacquesa Tati i Romaine Gary'ego; laureat Międzynarodowej Nagrody Bookera w dziedzinie przekładu (2005). Ostatnio opublikował monografię pt. The Novel of the Century: The Extraordinary Adventure of Les Misérables (2017), za którą otrzymał nagrodę American Library w Paryżu. 